\title{
Nerve Growth Factor-Regulated Emergence of Functional $\delta$-Opioid Receptors
}

\author{
Bihua Bie, ${ }^{1}$ Zhi Zhang, ${ }^{1}$ You-Qing Cai, ${ }^{1}$ Wei Zhu, ${ }^{1}$ Yong Zhang, ${ }^{1}$ Jaile Dai, ${ }^{2}$ Charles J. Lowenstein, ${ }^{3,4}$ \\ Edward J. Weinman, ${ }^{5}$ and Zhizhong Z. Pan ${ }^{1}$ \\ ${ }^{1}$ Department of Anesthesiology and Pain Medicine, The University of Texas-MD Anderson Cancer Center, Houston, Texas 77030, ${ }^{2}$ Department of Molecular \\ Pathology, The University of Texas-MD Anderson Cancer Center, Houston, Texas 77030, Departments of ${ }^{3}$ Medicine and ${ }^{4}$ Pathology, The Johns Hopkins \\ University School of Medicine, Baltimore, Maryland 21205, and 5Division of Nephrology, University of Maryland Hospital, Baltimore, Maryland 21201
}

Sorting of intracellular G-protein-coupled receptors (GPCRs) either to lysosomes for degradation or to plasma membrane for surface insertion and functional expression is a key process regulating signaling strength of GPCRs across the plasma membrane in adult mammalian cells. However, little is known about the molecular mechanisms governing the dynamic process of receptor sorting to the plasma membrane for functional expression under normal and pathological conditions. In this study, we demonstrate that $\delta$-opioid receptor (DOPr), a GPCR constitutively targeted to intracellular compartments, is driven to the surface membrane of central synaptic terminals and becomes functional by the neurotrophin nerve growth factor (NGF) in native brainstem neurons. The NGF-triggered DOPr translocation is predominantly mediated by the signaling pathway involving the tyrosine receptor kinase $\mathrm{A} \mathrm{Ca}^{2+}$-mobilizing phospholipase $\mathrm{C}$, and $\mathrm{Ca}^{2+} /$ calmodulin-dependent protein kinase II. Importantly, it requires interactions with the cytoplasmic sorting protein NHERF-1 $\left(\mathrm{Na}^{+} / \mathrm{H}^{+}\right.$exchange regulatory factor-1) and $N$-ethyl-maleimide-sensitive factor-regulated exocytosis. In addition, this NGFmediated mechanism is likely responsible for the emergence of functional DOPr induced by chronic opioids. Thus, NGF may function as a key molecular switch that redirects the sorting of intracellularly targeted DOPr to plasma membrane, resulting in new functional DOPr on central synapses under chronic opioid conditions.

\section{Introduction}

Surface density and signaling strength of G-protein-coupled receptors (GPCRs) on mammalian cell membrane are actively regulated by receptor trafficking through endocytosis (internalization) and exocytosis, two trafficking processes dynamically determined by agonist stimulation and molecular properties of the receptors (Hanyaloglu and von Zastrow, 2008). The mechanisms of GPCR internalization mediated by receptor phosphorylation and $\beta$-arrestin association upon agonist binding have been well characterized and are consistent among many different types of GPCRs, whereas the cellular fates of internalized GPCRs are rather diverse. Constitutively, GPCRs can be sorted to the lysosomal pathway for degradation or to the recycling pathway for surface membrane insertion through exocytosis (Tan et al., 2004; Hanyaloglu and von Zastrow, 2008). A typical example of this constitutive sorting of GPCRs is opioid receptors: while internalized $\mu$-opioid receptor (MOPr) is mostly directed to the recycling pathway for surface insertion, intracellular $\delta$-opioid receptor (DOPr) is normally sorted to the lysosomal pathway for degradation or is constitutively retained in intracellular compart-

\footnotetext{
Received 0ct. 26, 2009; revised Feb. 11, 2010; accepted March 9, 2010.

This work was supported by the National Institute on Drug Abuse Grants DA023069 and DA025826. We thank Dr.

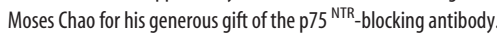

Correspondence should be addressed to Dr. Zhizhong Z. Pan, Department of Anesthesiology and Pain Medicine, Unit 110, The University of Texas-MD Anderson Cancer Center, 1515 Holcombe Boulevard, Houston, TX 77030. E-mail:zzpan@mdanderson.org.

D0I:10.1523/JNEUROSC1.5296-09.2010

Copyright $\odot 2010$ the authors $\quad 0270-6474 / 10 / 305617-12 \$ 15.00 / 0$
}

ments, resulting in a low level of functional DOPr on plasma membrane in many types of central neurons (Tsao and von Zastrow, 2000; Finn and Whistler, 2001; Wang and Pickel, 2001; Ma et al., 2006).

Recent studies show that the lysosomal sorting of DOPr is regulated by a GPCR-associated sorting protein (Whistler et al., 2002) and the predominant intracellular targeting of DOPr is retained by a specific domain in the cytoplasmic tail of DOPr, which is lacking in MOPr (Kim and von Zastrow, 2003). However, certain pathological conditions can alter the normal sorting of GPCRs and induce GPCR mislocalization with abnormal GPCR signaling, leading to a variety of diseases (Tan et al., 2004). For example, prolonged exposure to opioids induces exocytotic membrane trafficking of intracellular DOPr to surface membrane, resulting in new functional DOPr in central neurons involved in pain modulation and in drug addiction (Morinville et al., 2004; Hack et al., 2005; Ma et al., 2006; Zhang et al., 2006; Cahill et al., 2007; Bie et al., 2009). This mechanism of DOPr membrane trafficking has also been demonstrated in our previous confocal immunocytochemical study on brainstem neurons, which shows that chronic morphine recruits new functional DOPr on presynaptic terminals through DOPr translocation, with increased DOPr protein on plasma membrane and an increased number of DOPr-immunoreactive varicosities (presumably on presynaptic terminals) that appose postsynaptic membrane of cell bodies (Ma et al., 2006).

In contrast to the well characterized mechanism of GPCR internalization, little is known about the molecular mechanisms 
regulating the diverse sorting and membrane trafficking of intracellular GPCRs. Particularly, the molecular determinants that may alter the normal sorting destination of GPCRs and their cellular signaling under certain pathological conditions are unknown at present (Cahill et al., 2007; Hanyaloglu and von Zastrow, 2008). In this study, we used this morphine-induced DOPr as a functional measure of DOPr trafficking to investigate the mechanisms of its intracellular sorting and surface expression.

\section{Materials and Methods}

All procedures involving the use of animals conformed to the guidelines by the Institutional Animal Care and Use Committee of MD Anderson Cancer Center.

Animals and chronic morphine treatment. Male Wistar rats were treated with chronic morphine for $6 \mathrm{~d}$ by twice-daily injections of morphine solution with escalating doses $(10-30 \mathrm{mg} / \mathrm{kg}$, i.p.) as reported before (Bie et al., 2005; Ma et al., 2006). Saline was similarly injected in a separate group of rats as controls. $\mathrm{Na}^{+} / \mathrm{H}^{+}$exchange regulatory factor- 1 knockout $(\mathrm{KO})\left(\mathrm{NHERF}-1^{-1-}\right)$ mice, originally generated and reported previously (Shenolikar et al., 2002), were inbred and genotyped onsite, and similarly treated with chronic morphine. $\mathrm{DOPr}^{-1-}$ mice were purchased from The Jackson Laboratory.

Brain slice preparations. Neonatal rats (9-14 d), or NHERF-1 knockout and corresponding wild-type (WT) mice, were used for preparations of brainstem slices ( $250 \mu \mathrm{m}$ thick) containing the nucleus raphe magus (NRM) for whole-cell recording as previously described (Bie et al., 2005). A single slice was submerged in a shallow recording chamber and perfused with preheated $\left(35^{\circ} \mathrm{C}\right)$ physiological saline. Neonatal rats were used for better visualization of NRM neurons, and we have shown that the physiological and pharmacological properties of neurons from these young rats are indistinguishable from those of adult rats (Pan et al., 1997; Bie et al., 2005). The slice was generally treated with a specific inhibitor in vitro for a long $(4 \mathrm{~h})$ period, or a short $(30 \mathrm{~min})$ period for controls. The target specificity of those inhibitors at the concentration used has been documented previously (see supplemental material, available at www. jneurosci.org). Other drugs were applied through the bath solution.

Whole-cell recording and synaptic currents. Visualized whole-cell voltage-clamp recordings were obtained from identified NRM neurons with a glass pipette (resistance 3-5 M $\Omega$ ) filled with a solution containing the following (in $\mathrm{mM}$ ): $\mathrm{KCl}, 126 ; \mathrm{NaCl}, 10 ; \mathrm{MgCl}_{2}, 1$; EGTA, 11; HEPES, 10; ATP, 2; GTP, 0.25; pH adjusted to 7.3 with $\mathrm{KOH}$; osmolarity 280-290 $\mathrm{mOsm} / \mathrm{L}$. Electrical stimuli of constant current $(0.25 \mathrm{~ms}, 0.2-0.4 \mathrm{~mA})$ were used to evoke glutamate EPSCs or GABA IPSCs, as described in details previously (Bie et al., 2005; Ma et al., 2006). An inhibition by a drug was defined as a reduction of $>10 \%$ of control in the amplitude of synaptic currents. Miniature EPSCs were obtained in $60 \mathrm{~s}$ epochs in the presence of tetrodotoxin $(1 \mu \mathrm{M})$, and a sliding EPSC template custom defined with the acquisition software was used to detect and analyze the frequency and amplitude of miniature EPSCs.

Western blots. NRM tissues of rats $(200-250 \mathrm{~g})$ were harvested and standard Western blot experiments were performed as in our previous report (Ma et al., 2006). After tissue homogenization and lysis, samples were centrifuged and the supernatant was used for SDS-PAGE. Proteins were separated and electrotransferred onto nitrocellulose membrane. Samples were incubated overnight at $4^{\circ} \mathrm{C}$ with a primary antibody for nerve growth factor (NGF, 1:1000, Sigma, N6655, mouse), $\mathrm{Ca}^{2+}$ / calmodulin-dependent protein kinase II (CaMKII, 1:200, Santa Cruz Biotechnology, sc-9035, rabbit), phosphorylated CaMKII (p-CaMKII) (1:200, Santa Cruz Biotechnology, sc-32289, mouse), or NHERF-1 (1: 250, Santa Cruz Biotechnology, sc-71698, mouse), and for actin (1:200, Santa Cruz Biotechnology, sc-81178, mouse) or GAPDH (1:1000, Santa Cruz Biotechnology, sc-20357, goat) as controls (references to antibody specificity are available on the manufacturer's website). After washes, the blots were incubated with horseradish peroxidase-conjugated secondary antibody $(1: 10,000)$ (GE Healthcare) for $1 \mathrm{~h}$ and stained with 3,3'diaminobenzidine tetrahydrochloride. The amount of protein loaded in each lane is $20 \mu \mathrm{g}$. Immunoreactive proteins were detected by the enhanced chemiluminescence (ECL) Advance Kit (GE Healthcare). The intensity of bands was digitally captured and quantitatively analyzed with the software Kodak 1D (Eastman Kodak). The immunoreactivity of target proteins was normalized to that of actin or GAPDH.

Coimmunoprecipitation. NRM tissues were homogenized in a lysis buffer $(0.1 \%$ Triton X-100, $150 \mathrm{~mm} \mathrm{NaCl}, 25 \mathrm{~mm} \mathrm{KCl}$, and $10 \mathrm{~mm}$ Tris $\cdot \mathrm{HCl}, \mathrm{pH} 7.4$, with protease inhibitors and phosphatase inhibitors). Cleared lysate was incubated overnight at $4^{\circ} \mathrm{C}$ with rabbit polyclonal anti-DOPr antibody (1:100, Millipore Bioscience Research Reagents, AB1560) and precipitated for 5 h by protein A-agarose beads (Sigma). Precipitates were washed extensively, and the proteins were separated on a 10\% SDS-polyacrylamide gel and blotted to nitrocellulose membrane. The blots were incubated overnight at $4^{\circ} \mathrm{C}$ with monoclonal antiNHERF-1 antibody (1:250, Santa Cruz Biotechnology). The membrane was washed with Tris-buffered saline and incubated with anti-mouse IgG horseradish peroxidase (HRP) (1:10,000, GE Healthcare). The membrane was then reprobed with goat polyclonal anti-DOPr primary antibody (1:250, Santa Cruz Biotechnology, sc-7492) to detect immunoprecipitated DOPr. The DOPr-blocking peptide (Millipore) had the sequence LVPSARAELQSSPLV and was incubated with the DOPr antibody for 45 min before use. For serine/threonine phosphorylation of DOPr, the membrane was incubated with monoclonal anti-phosphoserine/threonine antibody (1:2000; BD Biosciences, 612548; mouse), extensively washed, and then incubated with anti-mouse IgG HRP $(1: 10,000)$ before ECL detection was performed. The total amount of DOPr was detected by incubating the stripped membranes with goat polyclonal anti-DOPr antibody (1:250, Santa Cruz Biotechnology).

Synaptosome preparations. As in our previous report (Bie et al., 2009), NRM tissues from saline- and morphine-treated rats were gently homogenized in ice-cold $0.32 \mathrm{M}$ sucrose buffer and centrifuged at $1000 \times g$ $\left(4^{\circ} \mathrm{C}\right)$. The supernatant was collected and centrifuged at $10,000 \times g$ $\left(4^{\circ} \mathrm{C}\right)$, and the synaptosomal pellet was resuspended in a lysis buffer with protease inhibitors. For total protein preparations (Ma et al., 2006), NRM tissues from saline- and morphine-treated rats were homogenized in the lysis buffer, the lysates were centrifuged at 14,000 rpm, and the supernatant was used for SDS-PAGE. Protein concentrations were determined by using the Bio-Rad protein assay kit.

Immunohistochemistry. Rats pretreated with morphine $(n=6)$ or saline $(n=6)$ were deeply anesthetized with $60 \mathrm{mg} / \mathrm{kg}$ sodium pentobarbital and perfused transcardially with $0.1 \mathrm{M}$ PBS followed by $4 \%$ formalin. The brainstem was collected, postfixed in the same fixative for $4 \mathrm{~h}$, and then cryoprotected in $30 \%$ sucrose in PBS for $3 \mathrm{~d}$. Serial sections $(30 \mu \mathrm{m}$, 15-20/rat) containing the NRM were cut from the fixed brainstem. The sections were incubated for at least $1 \mathrm{~h}$ in $0.01 \mathrm{M}$ PBS with $0.3 \%$ Triton X-100 plus 5\% normal donkey serum. Primary and secondary antibodies were diluted in $0.01 \mathrm{M}$ PBS with $0.3 \%$ Triton X-100 plus $1 \%$ bovine serum. Sections were processed overnight at $4^{\circ} \mathrm{C}$ for double-labeling immunofluorescence using rabbit antibody directed against NGF (1:100, Santa Cruz Biotechnology, sc-548) and mouse monoclonal antibody against the neuronal marker NeuN (1:500, Millipore Bioscience Research Reagents, MAB377). Then, the sections were incubated with a mixture of FITC- (1:500, Jackson ImmunoResearch, Lot No. 87017) and Cy3conjugated secondary antibodies (1:500, Jackson ImmunoResearch, Lot No. 88464) for 1 h. The stained sections were examined with a Nikon E600 fluorescence microscope (Nikon Instech), and images were captured with a CCD spot camera. Quantitative comparison of NGFpositive cells within the NRM between the two groups of rats was made manually in randomly selected sections.

Microinjection. As we described before (Bie et al., 2005; Ma et al., 2006), a rat was anesthetized with sodium pentobarbital (50 mg/kg i.p.) and restrained in a stereotaxic apparatus. A 26 gauge double-guide cannula (Plastics One) was inserted into the brain, aiming at the NRM (anteroposterior, $-10.0 \mathrm{~mm}$ from the bregma; lateral, 0; dorsoventral, $-10.5 \mathrm{~mm}$ from the dura) (Paxinos and Watson, 1986). The guide cannula was then cemented in place to the skull and securely capped. The rat was allowed to recover for at least $5 \mathrm{~d}$ before drug treatment. For in vivo treatment by microinjection, NGF $(0.05 \mu \mathrm{g} / 0.5 \mu \mathrm{l}), \mathrm{K} 252 \mathrm{a}(47 \mu \mathrm{g} / 1 \mu \mathrm{l})$, or saline was delivered into the NRM twice daily for $2 \mathrm{~d}$ through a 33 gauge double injector with an infusion pump at a rate of $0.2 \mu \mathrm{l} / \mathrm{min}$. The 
injection sites for the NRM were histologically verified afterward by injecting $0.5 \mu$ l of a blue dye.

Statistical analyses and materials. General numerical data were statistically analyzed with paired or unpaired Students' $t$ tests, or ANOVA where appropriate, and presented as mean \pm SEM. Statistical analysis of miniature EPSCs was performed using the Statview software with the Kolmogorov-Smirnov test. Morphine sulfate, deltorphin, and naltriben were supplied by the Drug Program of the National Institute on Drug Abuse. The $\mathrm{p} 75^{\mathrm{NTR}}$-blocking antibody was kindly provided by Dr. Moses Chao at New York University School of Medicine (New York, NY). Other drugs were purchased from Sigma-Aldrich or Tocris Bioscience.

\section{Results}

\section{Chronic morphine induces new functional DOPr on} presynaptic terminals of glutamate synapses

We first examined morphine-induced emergence of functional DOPr on glutamate synapses in brainstem neurons of the nucleus raphe magnus, which, under normal conditions, steadily express functional MOPr, but lack functional DOPr due to its predominant intracellular localization (Pan et al., 1997; Ma et al., 2006). In these neurons under whole-cell voltage-clamp recording in control slices taken from saline-treated rats $(n=12)$, the selective DOPr agonist deltorphin II $(1 \mu \mathrm{M})$ had no significant effect on the amplitude of evoked glutamatergic EPSC in any neuron tested (control, $136 \pm 11 \mathrm{pA}$, deltorphin, $132 \pm 11 \mathrm{pA}, n=21$, $p=0.30$ ) (Fig. $1 A$ ), indicating that functional DOPr is lacking on normal glutamate synapses in these neurons. By contrast, in neurons from chronic morphine-treated rats $(n=15)$, deltorphin ( 1 $\mu \mathrm{M})$ produced a reversible inhibition in the EPSC amplitude in every neuron tested (control, $170 \pm 12 \mathrm{pA}$, deltorphin, $112 \pm 8$ pA, $n=21, p<0.01$ ) (Fig. $1 B$ ). The deltorphin inhibition was dose dependent, with a near-maximum inhibition of $34 \pm 2 \%$ at $1 \mu \mathrm{M}$ and an $\mathrm{EC}_{50}$ value of $32.4 \mathrm{nM}$ (Fig. 1C), and it was completely abolished by the selective DOPr antagonist naltriben (50 $\mathrm{nM}$ ) (control in naltriben, $183 \pm 19 \mathrm{pA}$, + deltorphin, $172 \pm 19$ pA, $n=9, p=0.15$ ) (Fig. $1 D$ ). This indicates a selective DOPrmediated effect, as we reported previously (Ma et al., 2006).

To determine the synaptic site of this newly emerged DOPr, we first used the paradigm of paired-pulse ratio (PPR), which has an inverse relationship with the probability of presynaptic transmitter release and has been widely used to determine a presynaptic involvement in a synaptic change (Dobrunz and Stevens, 1997; Bie et al., 2005). In those brainstem neurons of control slices, deltorphin failed to alter the PPR of glutamate EPSCs (control, $1.77 \pm 0.06$, deltorphin, $1.73 \pm 0.09, n=10, p=0.48$ ) (Fig. $1 E, F)$. In neurons from morphine-treated rats, the baseline PPR was significantly decreased when compared to that of control neurons ( $1.25 \pm 0.05$ vs $1.77 \pm 0.06$ of controls, $p<0.01$ ), indicating a significantly increased activity of glutamate synapses by the morphine treatment, an observation consistent with our previous study on the same neurons (Bie et al., 2005). In these neurons of morphine-treated rats, however, deltorphin significantly increased the EPSC PPR (control, $1.25 \pm 0.05$, deltorphin, $1.68 \pm 0.06, n=10, p<0.01$ ) (Fig. $1 E, F$ ), indicating a likely decrease in presynaptic glutamate release. To further confirm this mechanism, we analyzed the properties of spontaneous miniature EPSCs in the presence of tetrodotoxin $(1 \mu \mathrm{M})$. We found that the DOPr agonist, while having no effect on either the frequency or amplitude of miniature EPSCs in neurons of control rats, significantly decreased the frequency of miniature EPSCs without altering the amplitude in neurons from morphine-treated rats (frequency: control, $9.80 \pm 0.51 \mathrm{~Hz}$, deltorphin, $6.08 \pm 0.42 \mathrm{~Hz}$, $p<0.01$; amplitude: control, $23.7 \pm 1.4 \mathrm{pA}$, deltorphin, $23.3 \pm$ $1.6 \mathrm{pA}, p=0.51, n=11$ ) (Fig. $1 G, H)$. As we reported previously
(Ma et al., 2006), deltorphin remained ineffective on the postsynaptic membrane conductance in those neurons as well as in control neurons. These results suggest that chronic morphine induces new functional DOPr that appears on presynaptic glutamate terminals, and DOPr activation inhibits glutamate release.

\section{NGF induces new functional DOPr on glutamate synapses}

Recent studies, including ours, have shown that this morphineinduced functional DOPr results from exocytotic membrane trafficking of intracellularly localized DOPr (Ma et al., 2006; Zhang et al., 2006; Cahill et al., 2007). We began our search for the molecular determinant that might be responsible for this morphine-induced DOPr translocation to surface membrane by testing a number of compounds that activate the signaling pathways known to be upregulated by chronic opioids (Williams et al., 2001), in an attempt to trigger similar DOPr translocation in naive, normal neurons in vitro. Treatment of control slices with the adenylyl cyclase activator forskolin $(10 \mu \mathrm{M})$, the cAMP ana$\log$ /protein kinase A activator 8-bromo-cAMP (1 mM), the protein kinase $\mathrm{C}$ (PKC) activator phorbol 12-myristate 13-acetate (1 $\mu \mathrm{M})$, or neuropeptide cholecystokinin ( $300 \mathrm{~nm}$ ) for up to $5 \mathrm{~h}$ all failed to induce deltorphin-mediated inhibition of glutamate EPSCs (data not shown).

However, in control slices $(n=10)$ treated with NGF $(100$ $\mathrm{ng} / \mathrm{ml})$ for a long period $(4 \mathrm{~h})$, deltorphin $(1 \mu \mathrm{M})$ produced a significant and reversible inhibition in the EPSC amplitude in 9 of $11(82 \%)$ neurons generally surveyed (control, $207 \pm 27 \mathrm{pA}$, deltorphin, $147 \pm 19 \mathrm{pA}$, wash, $195 \pm 33 \mathrm{pA}, n=9, p<0.01$; no significant effect on the remaining 2 cells) (Fig. $2 A, E$ ). The inhibition was reversed by the DOPr antagonist naltriben (50 nM) (control in naltriben, $180 \pm 17 \mathrm{pA}$, + deltorphin, $171 \pm 19 \mathrm{pA}$, $n=5$ of a separate group, $p=0.20$ ) (Fig. $2 B, E$ ). This NGF treatment itself did not appear to have a significant effect on basal EPSC amplitude when compared between control and NGFtreated slices $(p=0.28)$. Cotreatment of control slices $(n=5)$ with NGF $(100 \mathrm{ng} / \mathrm{ml})$ and the tyrosine receptor kinase (TrK) inhibitor K252a (200 nM) for the same time period blocked the deltorphin effect (control, $191 \pm 39 \mathrm{pA}$, deltorphin, $186 \pm 34 \mathrm{pA}$, $n=5, p=0.50$ ) (Fig. $2 E$ ); so did the cotreatment with NGF plus the specific TrKA receptor antagonist GW441756 (100 nM) (control, $124 \pm 11 \mathrm{pA}$, deltorphin, $121 \pm 10 \mathrm{pA}, n=7$ from 7 slices, $p=0.43)$, but not with a blocking antibody (1:2000) to the other NGF receptor $75^{\mathrm{NTR}}$ (control, $188 \pm 26 \mathrm{pA}$, deltorphin, $127 \pm$ $21 \mathrm{pA}, n=5$ from 5 slices, $p<0.01$ ) (Fig. $2 C-E$ ). In contrast, treatment of control slices $(n=5)$ with NGF $(100 \mathrm{ng} / \mathrm{ml})$ for a short period (30 $\mathrm{min}$ ) was unable to induce functional DOPr on glutamate synapses (control, $157 \pm 22 \mathrm{pA}$, deltorphin, $150 \pm 25$ $\mathrm{pA}, n=5, p=0.45)$. We also determined whether NGF administered in intact rats in vivo would induce similar appearance of functional DOPr on glutamate synapses. In brainstem slices from naive rats $(n=6)$ treated with twice-daily NGF (100 ng, i.p.) for $2 \mathrm{~d}$, deltorphin $(1 \mu \mathrm{M})$ significantly and reversibly inhibited the EPSC in every neuron tested (control, $183 \pm 27 \mathrm{pA}$, deltorphin, $118 \pm 14 \mathrm{pA}$, wash, $171 \pm 15 \mathrm{pA}, n=6, p<0.01$ ) (Fig. $2 F)$.

Thus, it appears that long-term (at least hours) NGF treatment of both normal brainstem slices in vitro and naive rats in vivo, similar to the morphine treatment in vivo, is able to bring out functional DOPr on glutamate synaptic terminals by activating TrKA receptors.

\section{NGF is responsible for morphine induction of DOPr}

To determine whether NGF via TrKA receptors was responsible for morphine induction of DOPr, we first examined the effect of 
A
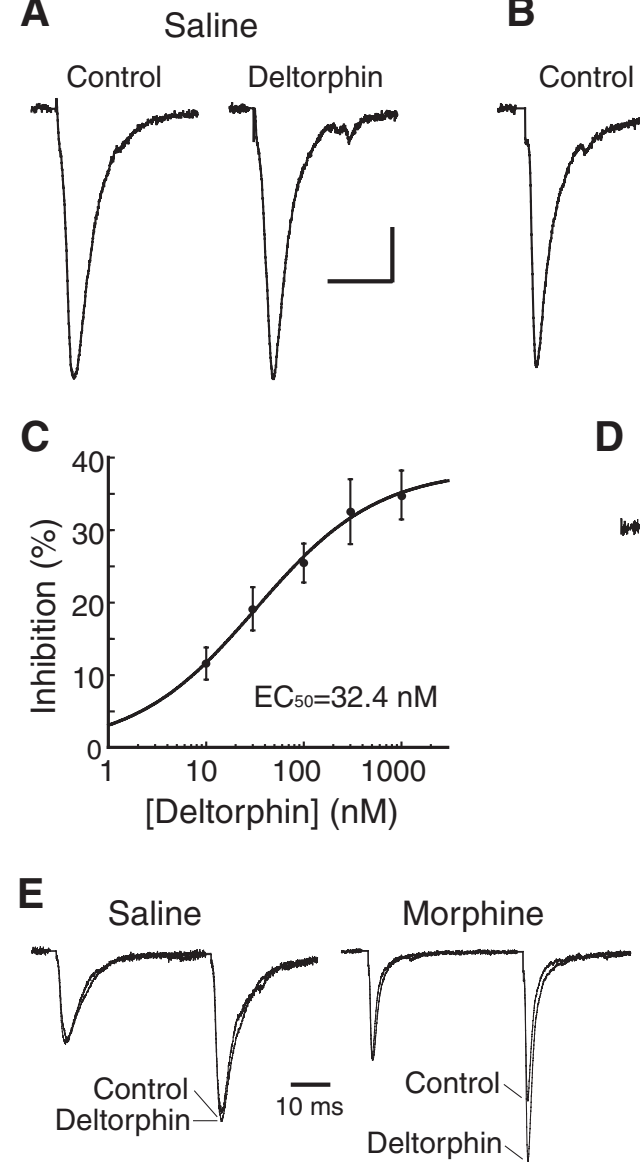

B

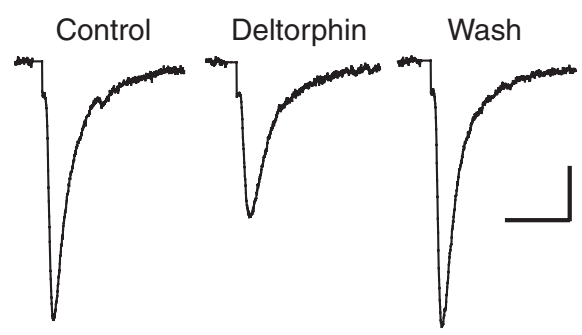

D

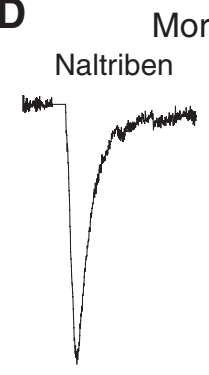

F

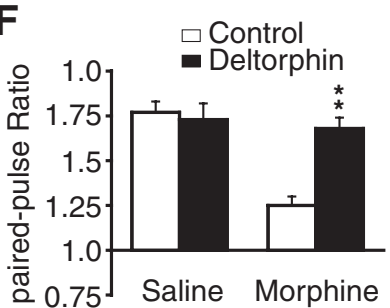

G

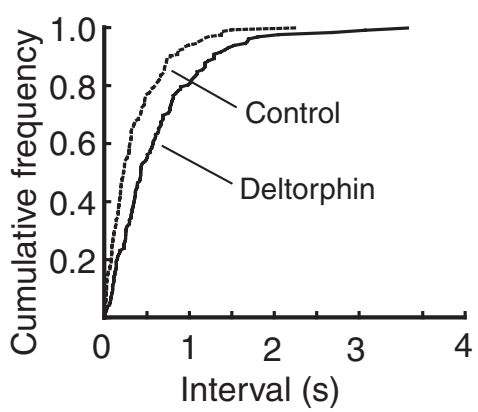

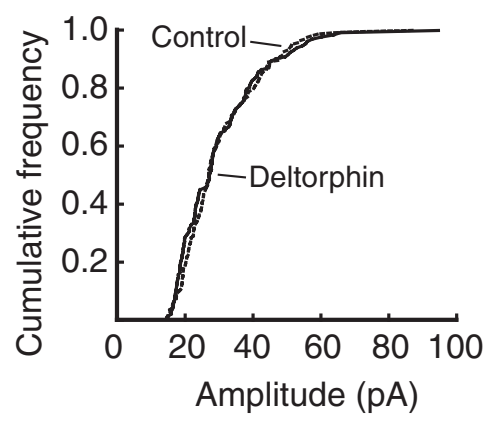

Amplitude (pA)

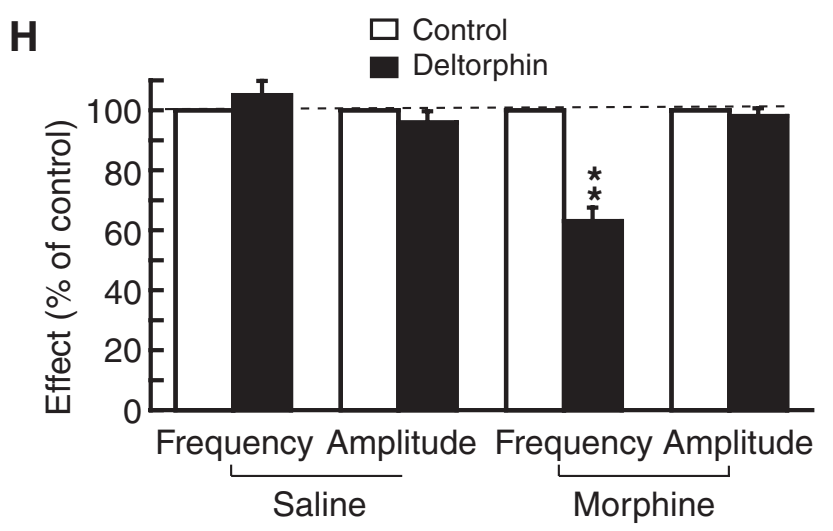

Figure 1. Chronic morphine induces new functional DOPr on presynaptic terminals. $A, B$, Representative glutamatergic EPSCS in control, in the presence of DOPr agonist deltorphin II (1 $\mu \mathrm{M})$, and after wash in a brainstem neuron of the NRM from a saline-treated rat $(\boldsymbol{A})$ and from a morphine-treated rat $(\boldsymbol{B})$. $\boldsymbol{C}, \mathrm{A}$ dose-response curve for the deltorphin inhibition of EPSCS in brainstem neurons ( $n=7-9$ cells at each dose) from morphine-treated rats. Error bars here and in all following figures are SEMs. D, EPSCs in the presence of the DOPr antagonist naltriben $(50 \mathrm{~nm})$ and after addition of deltorphin in a neuron from a morphine-

blocking TrKA receptors on the DOPr function in slices from morphine-treated rats. In those slices $(n=10)$ after treatment with GW441756 (100 nM) in vitro for $4 \mathrm{~h}$, deltorphin was no longer effective on EPSC amplitude in every cell tested (control, $160 \pm 16 \mathrm{pA}$, deltorphin, $153 \pm$ $17 \mathrm{pA}, n=11, p=0.18$ ) (Fig. 3A). The DOPr agonist also lost its inhibitory effect in the slices $(n=8)$ treated with K252a (200 nM) (control, $169 \pm 9 \mathrm{pA}$, deltorphin, $159 \pm 8 \mathrm{pA}, n=8, p=0.17$ ), but it remained effective after similar treatment of the slices $(n=7)$ with the blocking antibody to the p $75^{\mathrm{NTR}}$ receptor (control, $159 \pm 14 \mathrm{pA}$, deltorphin, $104 \pm 12 \mathrm{pA}$, $n=7, p<0.01$ ) (Fig. 3A). Further supporting the NGF involvement in morphineinduced functional translocation of DOPr, incubation of the slices $(n=7)$ with an anti-NGF antibody (1:4000) for $4 \mathrm{~h}$ also abolished the DOPr effect (control, $184 \pm 36 \mathrm{pA}$, deltorphin, $175 \pm 32$ pA, $n=9, p=0.38$ ) (Fig. 3A). Additional supporting evidence was obtained from Western blot experiments showing that brainstem tissues of the same nucleus, harvested from morphine-treated rats $(n=7)$, exhibited a significantly higher amount of NGF protein (normalized to actin proteins) when compared to brainstem tissues from control rats (to $248 \pm$ $42 \%$ of control, $n=7, p<0.01$ ) (Fig. $3 B$ ). This upregulated NGF expression was also observed in brainstem neurons from morphine-treated rats $(n=6)$, with an increased number of neurons immunocytochemically stained for NGF when compared to those from saline-treated rats $(n=6)$ (saline, $19 \pm 2$ cells/section; morphine, $46 \pm 4$ cells/section, $n=8$ sections for each group, $p<0.01$ ) (Fig. $3 C-G$ ). Furthermore, we cotreated rats with the same regimen of morphine plus the TrKA receptor antagonist GW441756 $(0.29 \mu \mathrm{g}$, i.p.) in vivo. In slices from those rats $(n=$ 5), deltorphin could no longer inhibit the EPSC in any cell tested (control, $201 \pm 41$ pA, deltorphin, $192 \pm 38 \mathrm{pA}, n=5, p=$ 0.13) (Fig. $3 H$ ). These results support the

$\leftarrow$

treated rat. $E$, Representative EPSC pairs superimposed and scaled to the amplitude of the first EPSC in a neuron from a saline- and a morphine-treated rat. $\boldsymbol{F}$, Group data of the deltorphin effect on the paired-pulse ratios of EPSCs in neurons from the two rat groups ( $n=10$ in each group). $\mathbf{G}$, Distribution graphs of miniature EPSC frequencies and amplitudes in a neuron from a morphine-treated rat. $\boldsymbol{H}$, Summarized deltorphin effects on the frequency and amplitude of miniature EPSCS in neurons of saline-treated rats $(n=10)$ and morphinetreated rats $(n=11) .{ }^{* *} p<0.01$. Calibration: $50 \mathrm{pA}$ and $10 \mathrm{~ms}$. 
A

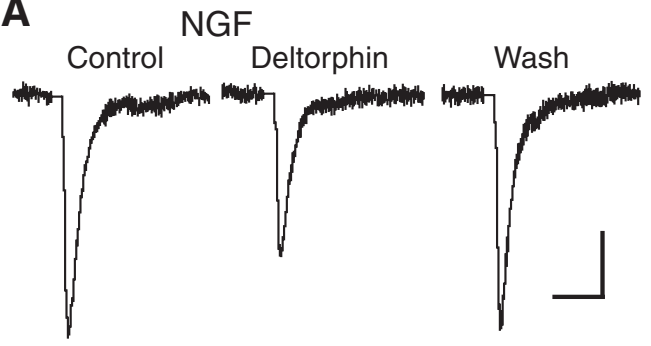

B NGF Naltriben +Deltorphin

C

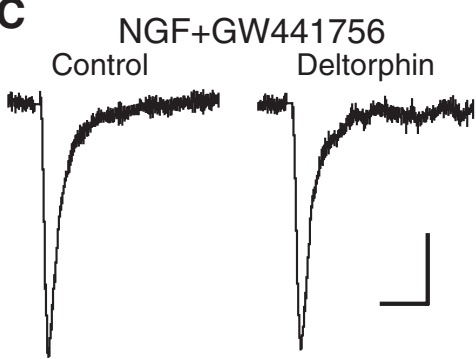

E

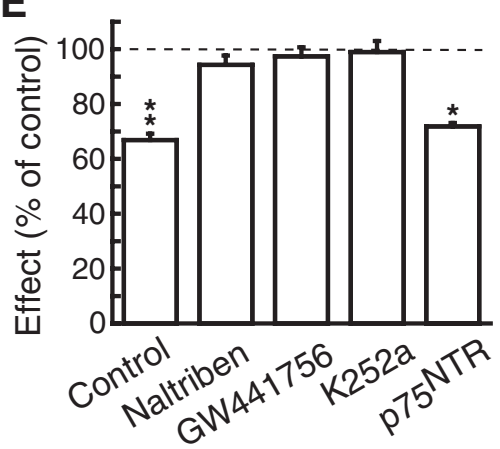

D NGF+p $75^{\mathrm{NTR}}$ antibody

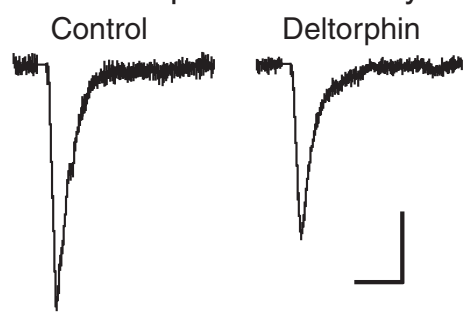

$\mathbf{F}$

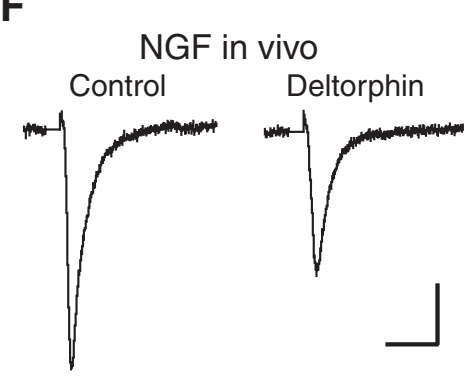

Figure 2. NGF induces new functional DOPr on glutamate synapses. $A$, Representative glutamate EPSCs before (control), during and after (wash) application of deltorphin ( $1 \mu \mathrm{M}$ ) from an NRM neuron in a normal slice taken from a naive rat and treated in vitro with NGF for a long period (4h). B, EPSCs in naltriben without and with deltorphin in an NGF-treated normal slice. C, D, EPSCs in a normal slice treated with NGF plus the TrKA receptor inhibitor GW441756 (100 nM, C) or plus an anti-p75 ${ }^{\text {NTR }}$ receptor antibody (D). $\boldsymbol{E}$, Group data of the deltorphin effects on EPSCs in normal slices treated with long-period NGF alone (control, $n=9$ ), in the presence of naltriben, or treated with NGF plus an inhibitor as indicated. $F$, Deltorphin inhibition of EPSCs from a naive rat treated with repeated NGF in vivo. ${ }^{*} p<0.05,{ }^{* *} p<0.01$. Calibration: $50 \mathrm{pA}$ and $10 \mathrm{~ms}$.

notion that NGF via its TrKA receptors is a critical signaling molecule for morphine induction of functional DOPr on glutamate terminals.

\section{NGF induces functional DOPr on GABA synapses}

We have previously reported that morphine also induces new functional DOPr through membrane trafficking on GABAergic terminals in these brainstem neurons (Ma et al., 2006). We then determined whether NGF induction of DOPr would also occur on GABA synapses in these brainstem neurons. We found that, in normal slices treated similarly with NGF for $4 \mathrm{~h}$ in vitro, deltorphin $(1 \mu \mathrm{M})$ produced a significant and reversible inhibition in the amplitude of GABA-mediated IPSCs in 12 of $20(60 \%)$ neurons generally surveyed (control, $228 \pm 29 \mathrm{pA}$, deltorphin, $135 \pm$ $17 \mathrm{pA}, n=12, p<0.01$ ) (Fig. $4 A, B$ ). The averaged magnitude of inhibition was $39.7 \pm 3.0 \%$. The DOPr antagonist naltriben $(50$ $\mathrm{nM}$ ) abolished this deltorphin effect (control in naltriben, $181 \pm$ $26 \mathrm{pA}$, + deltorphin, $179 \pm 23 \mathrm{pA}, n=6, p=0.54)$ (Fig. $4 A, B$ ). Acute or a short-period $(<30 \mathrm{~min})$ application of NGF $(100$ $\mathrm{ng} / \mathrm{ml}$ ) failed to induce functional DOPr on GABA synapses in control slices (control, $254 \pm 24 \mathrm{pA}$, deltorphin, $241 \pm 26 \mathrm{pA}$, $n=10, p=0.16)$. In contrast, in slices from morphine-treated rats and treated with the TrK receptor inhibitor K252a (200 nM) for $4 \mathrm{~h}$ in vitro, deltorphin was no longer effective on GABA IPSCs in every cell tested (control, $283 \pm 56 \mathrm{pA}$, deltorphin, $273 \pm 54 \mathrm{pA}$, $n=10, p=0.31$ ) (Fig. $4 C$ ). In similar slices of morphine-treated rats and kept in vitro for the same time period but without the TrK inhibitor, deltorphin significantly inhibited the GABA IPSCs (control, $287 \pm 62 \mathrm{pA}$, deltorphin, $171 \pm 40$ $\mathrm{pA}, n=6, p<0.01)$. This indicates that NGF may have a broader role in regulating synaptic DOPr trafficking and functions on central synapses.

\section{Signaling pathways for DOPr induction}

TrKA receptors are known to signal through three main pathways: the phospholipase C (PLC $\gamma$ ) pathway, the phosphatidylinositol 3 (PI3)-kinase pathway, and the Ras/mitogen-activated protein kinase (MAPK) pathway (Sofroniew et al., 2001; Huang and Reichardt, 2003). We next determined which pathway was predominantly involved in the morphine induction of DOPr by treating slices from morphine-treated rats with a specific inhibitor for a long period (3-4 h). In those slices $(n=10)$ treated with the PLC inhibitor U73122 $(2 \mu \mathrm{M})$, deltorphin no longer produced any inhibition of glutamate EPSCs (control, $149 \pm 23 \mathrm{pA}$, deltorphin, $140 \pm 23 \mathrm{pA}, n=11, p=0.16$ ) (Fig. $5 A$ ). Treatment of the slices $(n=7)$ with wortmannin $(1 \mu \mathrm{M})$, a potent inhibitor of PI3kinase, also antagonized the deltorphin effect (control, $206 \pm 34 \mathrm{pA}$, deltorphin, $191 \pm 30 \mathrm{pA}, n=7, p=0.12$ ), but not a similar treatment of the slices $(n=7)$ with the potent inhibitor of MAPK kinase U0126 $(10 \mu \mathrm{M})$ (control, $152 \pm 24 \mathrm{pA}$, deltorphin, $95 \pm 17 \mathrm{pA}$, $n=7, p<0.05$ ) (Fig. 5A). This suggests that both the PLC $\gamma$ pathway and the PI3-kinase pathway are important for morphine induction of DOPr.

Given the $\mathrm{Ca}^{2+}$ dependence of vesicle fusion with plasma membrane involved in receptor exocytosis and $\mathrm{Ca}^{2+}$ dependence of agonist-induced rapid (in seconds) receptor trafficking (Lin and Scheller, 2000; Zhang et al., 2006), we further explored the $\mathrm{Ca}^{2+}$-mobilizing PLC $\gamma$ pathway to identify the downstream signaling molecules. The major products of PLC $\gamma$ activation are diacylglycerol (DAG) and inositol 1,4,5-trisphosphate (IP3), and the latter regulates $\mathrm{Ca}^{2+}$ release from IP3-sensitive $\mathrm{Ca}^{2+}$ stores. Long-period treatment of slices $(n=7)$ from morphine-treated rats with the IP3 receptor inhibitor 2-APB $(50 \mu \mathrm{M})$ blocked morphine-induced DOPr function (control, $155 \pm 18 \mathrm{pA}$, deltorphin, $152 \pm 20 \mathrm{pA}, n=7, p=0.59$ ), as did similar treatment of the slices $(n=11)$ with another IP3 receptor inhibitor heparin $(200 \mu \mathrm{g} / \mathrm{ml})$ (control, $137 \pm 17 \mathrm{pA}$, deltorphin, $124 \pm 16 \mathrm{pA}, n=$ $20, p=0.12$ ) (Fig. 5B). The involvement of intracellular $\mathrm{Ca}^{2+}$ release was further supported by the observation that depleting intracellular $\mathrm{Ca}^{2+}$ stores with long-period thapsigargin $(5 \mu \mathrm{M})$ also abolished the DOPr function in those slices $(n=10)$ (con- 
A
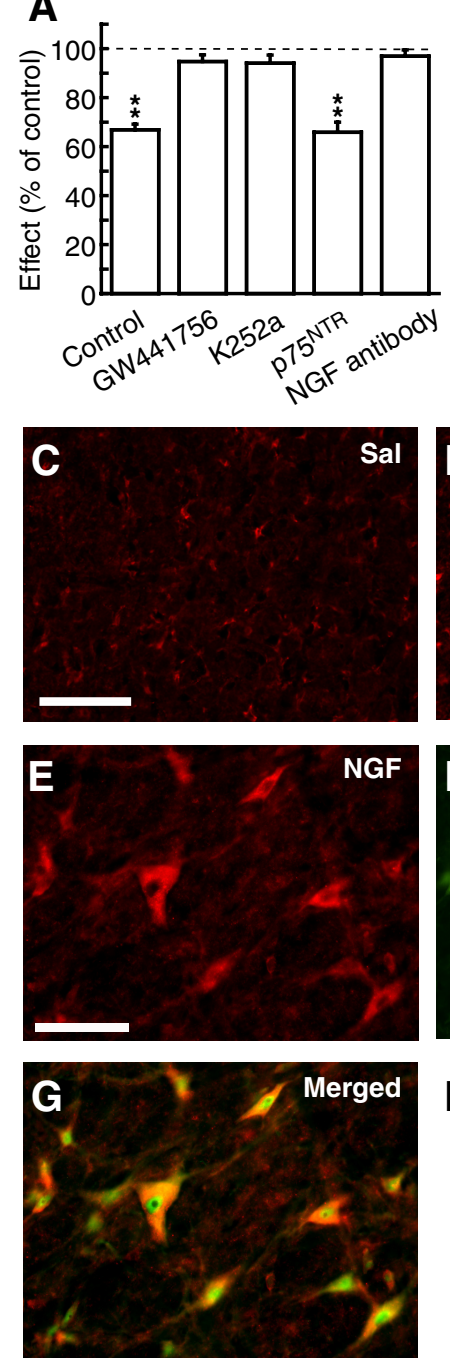

B
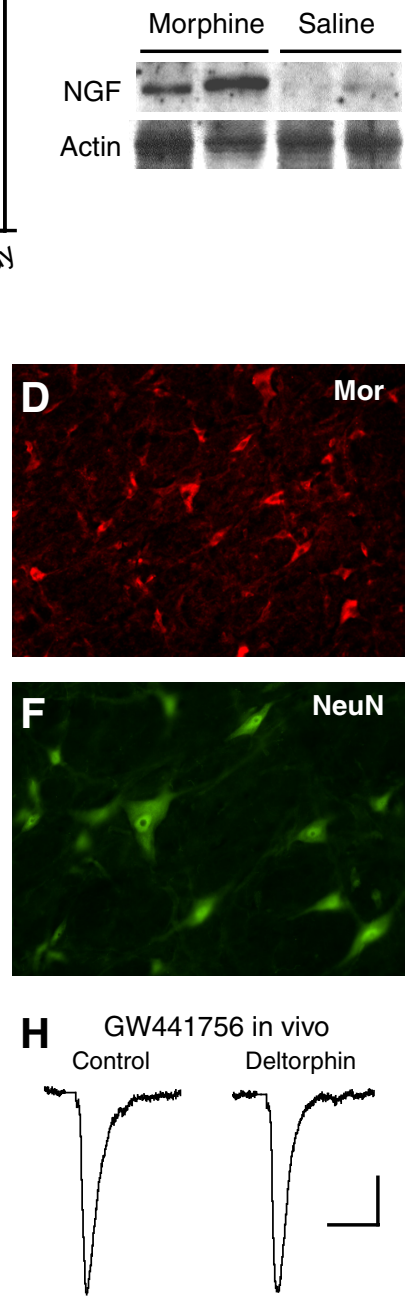

Figure 3. NGF is responsible for morphine induction of functional DOPr. A, Summarized deltorphin effects on EPSCs in slices of morphine-treated rats in control or after treatment in vitro with the indicated inhibitor. $\boldsymbol{B}$, Representative Western blot lanes of NGF and actin proteins in NRM tissues taken from saline- and morphine-treated rats. $\boldsymbol{C}, \boldsymbol{D}$, Microscopic images of immunofluorescence labeling for NGF in NRM sections from saline (Sal)- and morphine (Mor)treated rats. Calibration: $100 \mu \mathrm{m}$. $\boldsymbol{E}-\mathbf{G}$, Images of labeling for NGF (red) and for neurons with the neuronal marker NeuN (green), and a merged image in NRM slices from a morphine-treated rat. Calibration: $20 \mu \mathrm{m}$. H, EPSCs from a rat treated with morphine plus GW441756 in vivo. ${ }^{* *} p<0.01$. Calibration: $50 \mathrm{pA}$ and $10 \mathrm{~ms}$.

trol, $154 \pm 20 \mathrm{pA}$, deltorphin, $147 \pm 18 \mathrm{pA}, n=14, p=0.17)$ (Fig. $5 B$ ). In addition, morphine induction of DOPr appeared to be also dependent on $\mathrm{Ca}^{2+}$ entry through store-operated $\mathrm{Ca}^{2+}$ channels (SOCCs), as long-period treatment of the slices $(n=11)$ with MRS1845 (5 $\mu \mathrm{M})$, a potent SOCC blocker, eliminated the deltorphin effect (control, $140 \pm 13 \mathrm{pA}$, deltorphin, $127 \pm 13 \mathrm{pA}$, $n=13, p=0.15)$ (Fig. $5 B)$. In contrast, in the slices $(n=6)$ similarly treated with long-period GF109203X (3 $\mu \mathrm{M})$, a selective inhibitor of PKC, which is the substrate of DAG, deltorphin retained its inhibition of glutamate EPSCs (control, $256 \pm 76 \mathrm{pA}$, deltorphin, $164 \pm 57 \mathrm{pA}, n=6, p<0.05$ ) (Fig. $5 B$ ).

Increased activity of CaMKII, a serine/threonine kinase, has been shown to drive rapid (in seconds) membrane insertion of AMPA glutamate receptors into synapses through interactions between GluR1 subunits of AMPA receptors and cytoplasmic proteins containing the PSD-95-Dlg-ZO1 (PDZ) domains (Hayashi et al.,

A

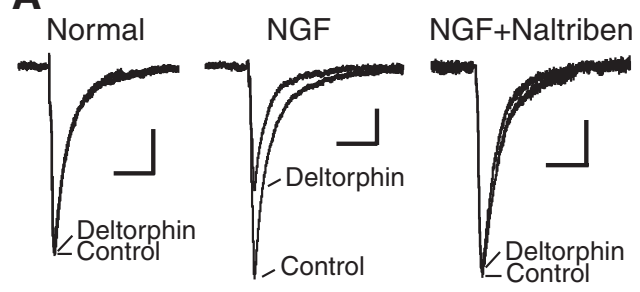

B

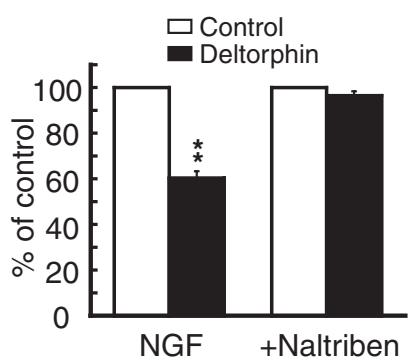

C

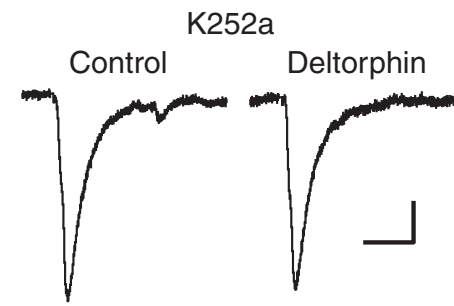

Figure 4. NGF mediates morphine induction of DOPr on GABA synapses. $\boldsymbol{A}$, Superimposed GABA-mediated IPSC in control and in deltorphin (1 $\mu \mathrm{m})$ in NRM neurons in a normal slice and in normal slices treated with NGF ( $100 \mathrm{ng} / \mathrm{ml}$ ) alone or with NGF plus naltriben ( $50 \mathrm{~nm})$ for $4 \mathrm{~h}$ in vitro. $\boldsymbol{B}$, Group data of the deltorphin effects after treatment of normal slices with NGF or NGF plus naltriben. $C$, Representative GABA IPSCs in slices from morphine-treated rats and treated with the TrK receptor inhibitor $\mathrm{K} 252 \mathrm{a}$ (200 nm) for $4 \mathrm{~h}$ in vitro. Note that use of $\mathrm{KCl}$ in the intrapipette solution with a holding potential of $-60 \mathrm{mV}$ resulted in a downward direction of the IPSCs. ${ }^{* *} p<0.01$. Calibration: 50 pA and $20 \mathrm{~ms}$.

2000; Collingridge et al., 2004). Considering the $\mathrm{Ca}^{2+}$ dependence of this DOPr induction, we were wondering whether $\mathrm{Ca}^{2+}$-dependent activation of CaMKII was also required, although unlike the ligand-gated ion channel AMPA receptor, induction of membrane trafficking of DOPr, a GPCR, is a much slower (at least hours) process (Cahill et al., 2007). Nevertheless, in slices $(n=10)$ from morphine-treated rats and treated with the specific CaMKII inhibitor KN-93 (5 $\mu \mathrm{M})$ for a long period, the DOPr agonist was no longer effective (control, $191 \pm 16 \mathrm{pA}$, deltorphin, $183 \pm 18 \mathrm{pA}, n=11, p=0.45$ ) (Fig. 5C), whereas it inhibited EPSCs after similar treatment with the inactive analog KN-92 $(5 \mu \mathrm{M})$ (control, $164 \pm 20 \mathrm{pA}$, deltorphin, $110 \pm 13 \mathrm{pA}$, $n=12$ from 10 slices, $p<0.01$ ) (Fig. $5 C$ ). In further support of this CaMKII role, brainstem tissues taken from morphinetreated rats contained a significantly higher level of phosphorylated CaMKII proteins, the activated form of CaMKII, with the total CaMKII protein unchanged from controls (Fig. 5D,E).

As controls for the effects of all inhibitors we used, a shortperiod $(30 \mathrm{~min})$ treatment of slices from morphine-treated rats with those inhibitors failed to significantly alter morphineinduced DOPr function (see supplemental material, available at www.jneurosci.org).

\section{Sorting of DOPr}

Next, we sought other signaling proteins, downstream of CaMKII activation, which might account for altering the normal, intracel- 
A

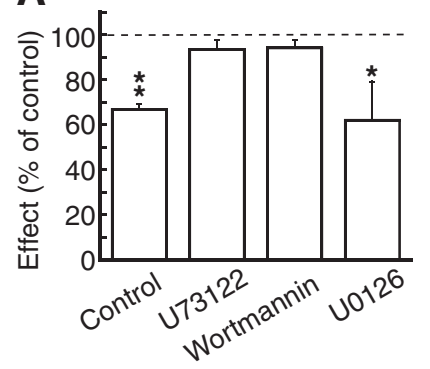

B
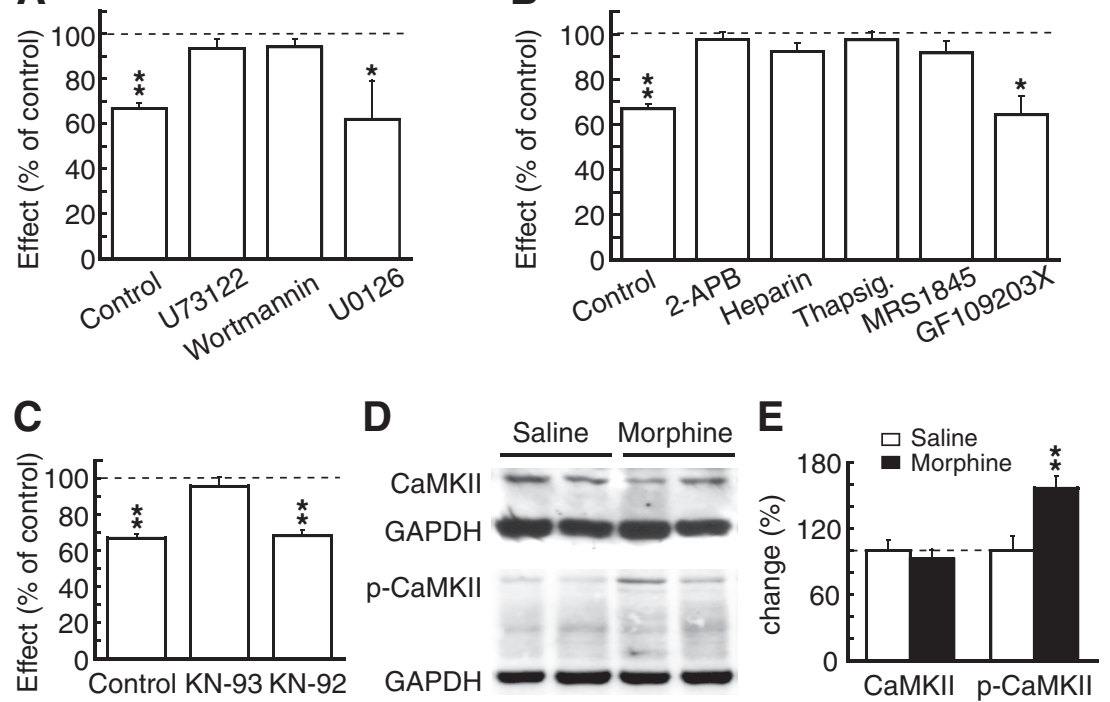

Figure 5. Morphine induction of DOPr involves the PLC-CaMKII pathway. A-C, Group data of deltorphin effects on EPSCS in slices from morphine-treated rats in control or treated in vitro with the indicated inhibitor for a long period. $\boldsymbol{D}$, Representative lanes of CaMKII, p-CaMKII, and GAPDH proteins in NRM tissues from saline- and morphine-treated rats. $\boldsymbol{E}$, Summarized Western blot results of percentage changes in CaMKII and p-CaMKII proteins normalized to GAPDH. Thapsig, Thapsigargin. ${ }^{*} p<0.05,{ }^{* *} p<0.01$.

lular sorting fate of DOPr after prolonged exposure to morphine and NGF. One of the few such candidate proteins currently known is NHERF-1, also known as EBP50 (ezrin-radixinmoesin-binding phosphoprotein-50), which is a PDZ domaincontaining scaffolding protein implicated in the assembly of protein complexes and in sorting of internalized $\beta_{2}$-adrenergic receptors and $\kappa$-opioid receptor (KOPr) to the recycling pathway for receptor resensitization (Liu-Chen, 2004; Weinman et al., 2006; Hanyaloglu and von Zastrow, 2008). We first examined whether the morphine treatment would change NHERF-1 expression. In brainstem tissues taken from morphine-treated rats $(n=8)$, we found that the protein level of NHERF-1, normalized to GAPDH, was significantly increased to $152 \pm 18 \%$ of control $(p<0.05)$ (Fig. 6A), raising the possibility that upregulated NHERF-1 protein changes the sorting fate of DOPr from normally intracellular targeting to exocytotic trafficking for membrane insertion and functional expression. This hypothesis was supported by our following experiments using coimmunoprecipitation (co-IP) to assess interaction between DOPr and NHERF-1 proteins. In control brainstem tissues, there was a low level of NHERF-1 protein that coprecipitated with DOPr (Fig. 6B, C), consistent with previous reports that NHERF-1 normally has low affinity to or interaction with the c-terminal of DOPr (Heydorn et al., 2004; Huang et al., 2004). However, in brainstem tissues from morphine-treated rats $(n=10)$, the amount of NHERF-1 protein that coprecipitated with DOPr was significantly increased [Fig. $6 B$ (top two panels), $C$ ]. In contrast, after incubation of the DOPr antibody with a sequence-specific DOPrblocking peptide (Patwardhan et al., 2005), no DOPr or NHERF-1 protein was detected in the precipitated preparations following the same IP procedure (Fig. $6 B$, bottom two panels), indicating a sequence-specific binding of the DOPr antibody used for DOPr coIP. Additionally, this specific binding of DOPr by the DOPr antibodies is supported by the loss of DOPr immunostaining in DOPr KO mice (see supplemental material, available at www.jneurosci.org).

Demonstrating a specific role of TrK receptors in this increased NHERF-1-DOPr interaction, cotreatment of rats $(n=5)$ with morphine and the $\mathrm{TrK}$ receptor antagonist $\mathrm{K} 252 \mathrm{a}$ in vivo significantly inhibited the morphineinduced increase in NHERF-1-DOPr coprecipitation (Fig. 6C). In addition, morphine treatment also increased the serine/threonine phosphorylation of DOPr ( $n=13$ rats), which was blocked by cotreatment in vivo with morphine and $\mathrm{K} 252 \mathrm{a}$ ( $n=$ 5 rats) (Fig. 6D). A similar increase in NHERF-1-DOPr coprecipitation was also observed in brainstem tissues from naive rats $(n=6)$ treated with NGF (50 ng/0.5 $\mu \mathrm{l})$ in vivo through microinjections into the brainstem nucleus (NHERF/DOPr ratio: saline, $0.36 \pm 0.07, \mathrm{NGF}, 0.75 \pm 0.07, p<$ 0.01 ) (Fig. $6 E$ ). The NGF treatment of naive rats in vivo ( $n=6$ rats) also increased the amount of phosphorylated DOPr (pDOPr/ DOPr ratio: saline, $0.40 \pm 0.04$, NGF, $0.61 \pm 0.04, p<0.01$ ) (Fig. $6 F$ ).

\section{DOPr in NHERF-1 knock-out mice}

To further validate the specificity of DOPr-NHERF-1 interaction and its role in the DOPr trafficking, we examined the effects of morphine and NGF on DOPr induction in NHERF-1 KO mice we originally reported (Shenolikar et al., 2002). In saline-treated NHERF$1^{-/-}$mice and corresponding WT mice, deltorphin $(1 \mu \mathrm{M})$ was ineffective on the amplitude of glutamate EPSCs in the brainstem neurons (WT: control, $209 \pm 14 \mathrm{pA}$, deltorphin, $198 \pm 14 \mathrm{pA}$, $n=6, p=0.38$; KO: control, $292 \pm 8 \mathrm{pA}$, deltorphin, $285 \pm 7 \mathrm{pA}$, $n=7, p=0.37$ ) (Fig. $7 A, E$ ). In morphine-treated WT mice, functional DOPr, similar to that in morphine-treated rats, emerged as shown by deltorphin inhibition of EPSCs (control, $173 \pm 11 \mathrm{pA}$, deltorphin, $109 \pm 7 \mathrm{pA}, n=6, p<0.01$ ), but it was absent in the $\mathrm{KO}$ mice treated similarly with morphine (control, $234 \pm 7$ pA, deltorphin, $253 \pm 8 \mathrm{pA}, n=11, p=0.29$ ) (Fig. $7 B, E)$. Moreover, the same long-period NGF treatment of brainstem slices from naive WT mice induced functional DOPr on glutamate synapses in 6 of 8 cells (control, $201 \pm 18$ pA, deltorphin, $130 \pm 13 \mathrm{pA}, n=6, p<0.01$ ), but failed to do so in any cell tested in slices from naive $\mathrm{KO}$ mice (control, $257 \pm 8 \mathrm{pA}$, deltorphin, $252 \pm 8 \mathrm{pA}, n=10, p=0.46$ ) (Fig. 7C,E). In addition, morphine-induced DOPr function in WT mice was also abolished by long-period treatment of the slices in vitro with the TrK receptor antagonist $\mathrm{K} 252 \mathrm{a}(200 \mathrm{nM})$ (control, $138 \pm 6 \mathrm{pA}$, deltorphin, $133 \pm 7 \mathrm{pA}, n=5, p=0.36$ ) (Fig. $7 D, E)$. The expression of DOPr protein in the NHERF-1 KO mice was not significantly changed from that in the WT mice (DOPr/actin ratio: WT, $0.75 \pm 0.04, n=5 ; \mathrm{KO}, 0.72 \pm 0.06, n=6, p=0.72)($ Fig. $7 F)$. These findings from NHERF-1-lacking mice further support our results from rats by showing that NHERF-1 is required for both morphine and NGF induction of synaptic DOPr.

\section{Translocation of DOPr to surface membrane}

To determine whether the emerged DOPr on synaptic terminals was indeed due to translocation of intracellular DOPr to surface membrane, we next examined the amount of DOPr protein on terminal membrane using brainstem preparations of synaptosomes, which contain mostly membrane structures of synaptic terminals with nearly no cell body contents and greatly reduced intraterminal contents (Ghijsen et al., 2003; Dunkley et al., 2008). In a previous study (Ma and Pan, 2006), we have shown that the 
morphine treatment does not significantly change the total DOPr protein in the brainstem tissue. However, we found that, in brainstem synaptosomes from morphine-treated rats, the amount of DOPr protein, normalized to the specific synaptic terminal marker synaptophysin, was significantly increased when compared to controls, as revealed by Western blot analysis; this increase in synaptosomal DOPr was blocked by cotreatment of rats in vivo with morphine plus the TrK receptor antagonist K252a (Fig. 8A). Moreover, in rats treated with NGF in vivo that induced functional DOPr, the amount of synaptosomal DOPr protein was also significantly increased (Fig. $8 \mathrm{~A}$ ). Thus, it appears that the morphine and NGF induction of functional DOPr on synaptic terminals is likely due, at least partially, to DOPr translocation to surface membrane of synaptic terminals, consistent with our previous anatomical study of labeled DOPr with confocal microscopy on the same brainstem neurons ( $\mathrm{Ma}$ and Pan, 2006) and with our recent report of morphine-induced increase in synaptosomal DOPr of amygdala neurons (Bie et al., 2009). This notion is also in line with the mechanism for membrane trafficking of postsynaptic DOPr on dorsal root ganglion cells (Zhang et al., 2006; Cahill et al., 2007).

If the appearance of functional DOPr was indeed due to translocation or trafficking of intracellular DOPr to surface membrane rather than other mechanisms, it should be blocked in conditions under which known processes required for exocytotic receptor trafficking and membrane insertion were disrupted. The endoplasmic reticulum (ER) and the Golgi apparatus are important membrane network for packing and transporting of cytoplasmic proteins in receptor trafficking (Tan et al., 2004). In slices $(n=9)$ from morphine-treated rats and treated for $4 \mathrm{~h}$ with brefeldin A $(5 \mu \mathrm{M})$, an inhibitor of protein transportation from ER to the Golgi apparatus (Donaldson et al., 1992), deltorphin (1 $\mu \mathrm{M}$ ) could no longer inhibit the EPSC (control, $165 \pm 12 \mathrm{pA}$, deltorphin, $159 \pm 13 \mathrm{pA}, n=11, p=0.22$ ) (Fig. $8 B, G$ ).

Furthermore, to inhibit receptor exocytosis, we used a fusion polypeptide, TAT-NSF81 (5 $\mu \mathrm{M})$, which we have previously shown to block exocytosis by inhibiting $N$-ethyl-maleimidesensitive factor (NSF)-mediated disassembly of soluble NSF attachment protein receptor (SNARE) molecules (Matsushita et al., 2005). After the TAT-NSF81 treatment of slices from morphine-treated rats for $3 \mathrm{~h}$ in vitro, the slices were left in normal bath solution without the polypeptide for at least $20 \mathrm{~min}$ before EPSC recording. We found that TAT-NSF81 prevented deltorphin-induced inhibition of EPSCs in these slices $(n=8)$ (control, $153 \pm 20 \mathrm{pA}$, deltorphin, $142 \pm 17 \mathrm{pA}, n=10, p=0.47$ ) (Fig. $8 C, G$ ). By contrast, similar treatment with the corresponding but scrambled control peptide TAT-NSF81scr ( $5 \mu \mathrm{M})$ failed to alter the deltorphin inhibition of EPSCs (control, $198 \pm 23 \mathrm{pA}$, deltorphin, $135 \pm 24 \mathrm{pA}, n=7, p<0.01$ ) (Fig. 8D, G). Next, we ${ }^{* *} p<0.01$.
B

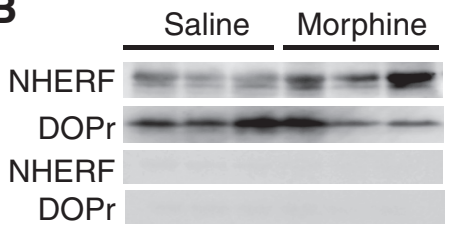

D
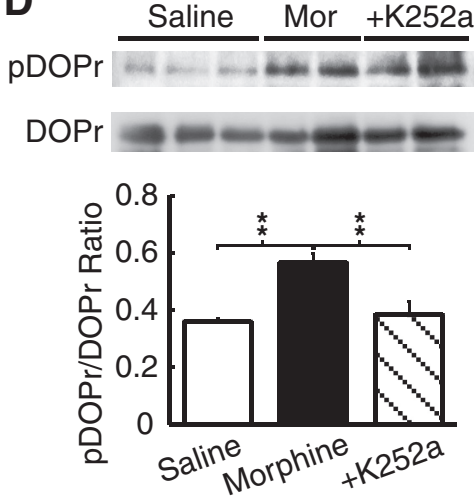

$\mathbf{F}$

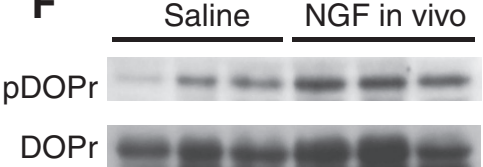

Figure 6. Chronic morphine increases interaction between DOPr and NHERF-1 proteins. $\boldsymbol{A}$, Western blot lanes of NHERF-1 and and $\operatorname{DOPr}(\boldsymbol{E})$ and for pDOPr and total DOPr $(\boldsymbol{F})$ in NRM tissues from naive rats treated with saline or NGF in vivo. Mor, Morphine.

confirmed that TAT-NSF81 did not inhibit signaling by other neuronal receptors constitutively localized on the plasma membrane, using $\mathrm{GABA}_{\mathrm{B}}$ receptor-mediated presynaptic inhibition as an example. In slices from morphine-treated rats, baclofen $(10 \mu \mathrm{M})$, a potent $\mathrm{GABA}_{\mathrm{B}}$ receptor agonist, produced a large inhibition in the EPSC amplitude (control, $289 \pm 57$ pA, baclofen, $141 \pm 39 \mathrm{pA}, n=7, p<0.01$ ) (Fig. $8 E, G$ ). This baclofen inhibition was largely due to activation of presynaptic $\mathrm{GABA}_{\mathrm{B}}$ receptors on glutamate synaptic terminals (B. Bie and Z. Z. Pan, unpublished observation). In slices that were comparable but pretreated similarly with TAT-NSF81 (5 $\mu \mathrm{M})$, baclofen $(10 \mu \mathrm{M})$ induced a similar EPSC inhibition (control, $201 \pm 23$ pA, baclofen, $89 \pm 12 \mathrm{pA}, n=8, p<0.01$ ) (Fig. $8 F, G)$. There was no statistical difference $(p=0.45)$ in the baclofen-induced EPSC inhibitions with and without the polypeptide treatment, indicating that TAT-NSF81 does not have a significant effect on the synaptic function of preexisting $\mathrm{GABA}_{\mathrm{B}}$ receptors on glutamate synapses. Thus, the recruitment of functional DOPr appears to require DOPr transportation from ER to Golgi and NSF-regulated vesicle exocytosis to the plasma membrane, two key processes for membrane trafficking of GPCRs (Tan et al., 2004). Figure $8 \mathrm{H}$ illustrates the proposed signaling pathways for chronic opioid-induced exocytotic trafficking and functional expression of DOPr on a central synaptic terminal. 
A Saline Wild Type

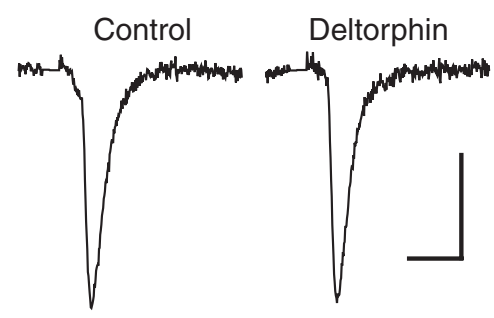

\section{B Morphine} Control

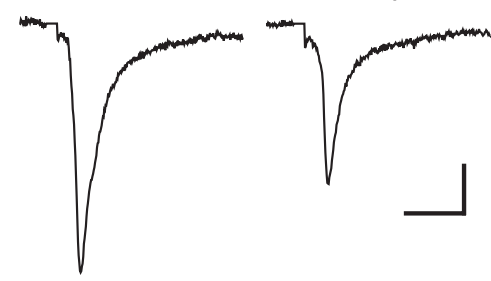

C NGF
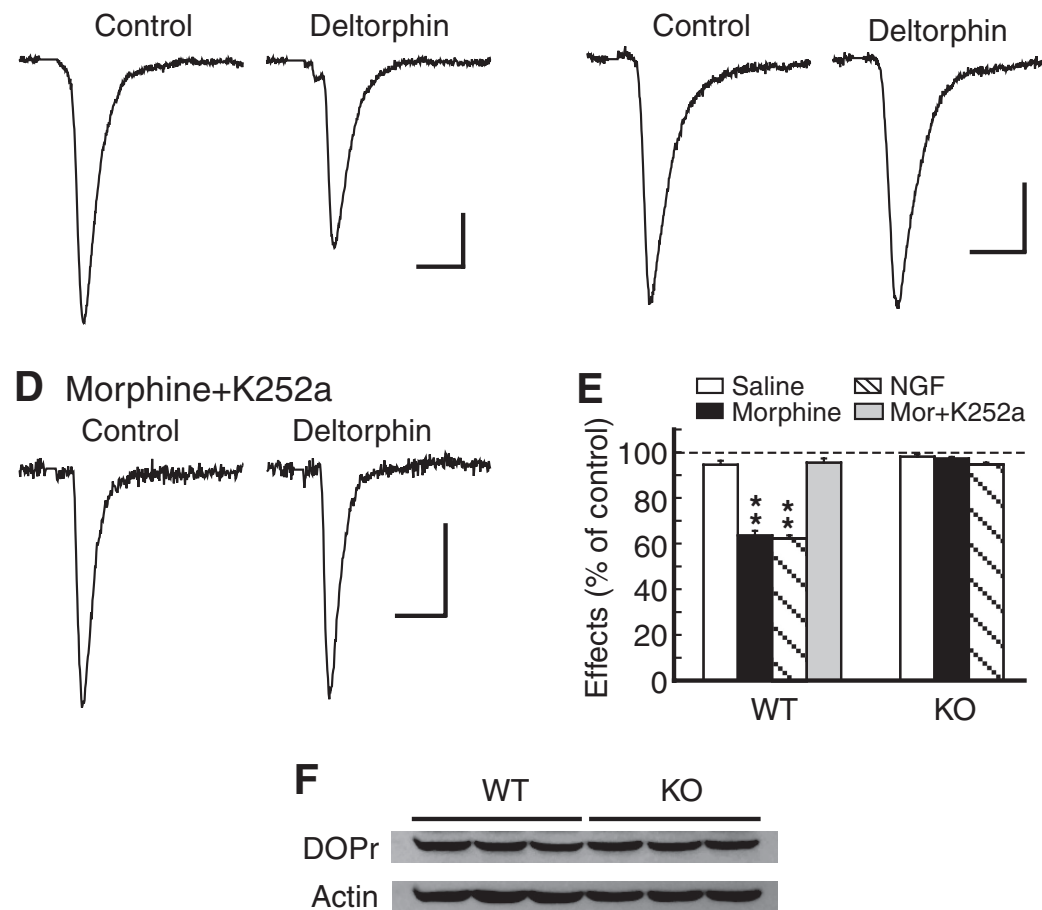

Figure 7. NHERF-1 is required for morphine and NGF induction of functional DOPr. $\boldsymbol{A}-\boldsymbol{D}$, Representative glutamate EPSCS in control and in deltorphin $(1 \mu \mathrm{M})$ in an NRM neuron from WT mice (left column) and NHERF-1 K0 mice (right column) treated with saline $(\boldsymbol{A})$, morphine $(\boldsymbol{B})$, from normal slices treated with long-period NGF $(\boldsymbol{C})$, or from a K252a-treated slice of a morphine-treated WT mouse (D). $\boldsymbol{E}$, Summarized data of the deltorphin effects in the four treatment groups of WT and KO mice. $\boldsymbol{F}$, Western blot lanes of DOPr and actin proteins in NRM tissues from WT $(n=5)$ and NHERF-1 KO mice $(n=6) .{ }^{* *} p<0.01$. Calibration: $50 \mathrm{pA}$ and $10 \mathrm{~ms}$.

\section{Discussion}

We have shown that long-period NGF, applied to central neurons both in vitro and in animals in vivo, causes the emergence of new functional DOPr on central synaptic terminals likely by redirecting constitutively intracellular DOPr to surface membrane, a mechanism that may account for chronic opioid-induced synaptic DOPr function. In addition, we have identified the prominent signaling pathway for the NGF effect, from TrKA receptors to exocytosis for surface insertion. Thus, NGF may function as a key molecular switch that alters the normal sorting of intracellular DOPr, redirecting intracellular DOPr to plasma membrane for functional expression under sustained opioid stimulation.

Classically, NGF has well known roles in neuronal survival and cell differentiation in the developing brain. Recent evidence has shown diverse trophic effects of NGF on the adult brain as well, particularly on structural modifications and synaptic efficacy in central synapses (Poo, 2001; Sofroniew et al., 2001; Chao and Bothwell, 2002). In cultured HEK 293 cells, NGF or epidermal growth factor rapidly (within minutes) increases membrane insertion of TRP channels by PI3 kinase-dependent phosphorylation (Zhang et al., 2005). The current study shows that, in native brain neurons, NGF causes translocation and surface expression of intracellular DOPr, a member of the GPCR superfamily representing the largest population of membrane receptors responsible for most of signaling across plasma membrane in mammalian cells (Tan et al., 2004). Thus, NGF may have much broader regulating functions in receptor signaling of the adult brain under both normal and pathological conditions.

Recent studies increasingly suggest that sorting of intracellular GPCRs to either lysosomes for degradation or endosomes for recycling is diverse and highly regulated by cytoplasmic sorting proteins. However, our understanding of GPCR sorting is still in its infancy, as only a few GPCR sorting proteins have been identified to date, in contrast to the vast number of GPCRs in brain neurons. For constitutive recycling under normal conditions, the PDZ domain-containing NHERF-1 is responsible for recycling of $\beta_{2^{-}}$ adrenergic receptors and $\mathrm{KOPr}$ (Liu-Chen, 2004; Hanyaloglu and von Zastrow, 2008), but has little interaction with DOPr as observed in heterologously expressing cell systems (Huang et al., 2004). Consistently, little NHERF-1-DOPr co-IP was observed in control, opioid-naive tissues in the present study. In contrast to constitutive sorting of GPCRs, little is known about the molecular mechanisms by which the normal sorting of GPCRs is altered under pathological conditions. Our results of significant NHERF-1-DOPr interaction, observed only after chronic morphine treatment and supported by results from NHERF-1 KO mice, indicate that NHERF-1 may possess a broader binding capacities and functional diversity in GPCR sorting and recycling under various conditions. It remains to be investigated how chronic opioids change NHERF-1-DOPr binding properties for their increased interaction, whether the increased DOPr phosphorylation we observed plays a role, and what specific C-terminal sequence of DOPr with certain phosphorylated sites is involved in the interaction. 
The intracellular retention of DOPr was shown to be maintained by DOPr binding to vesicle luminal substance $\mathrm{P}$ (SP), and upon agonist stimulation, SPbound DOPr in vesicles was rapidly (in seconds) inserted into plasma membrane in peripheral sensory neurons (Guan et al., 2005). However, that notion has been argued against by a recent study, using knock-in mice with a functional DOPreGFP fusion receptor in the same spinal neurons, showing that DOPr had no overlap with SP in expression and DOPr was trafficked independently of SP (Scherrer et al., 2009). Interestingly, NGF acutely $(<60$ $\mathrm{min}$ ) increases the intracellular pool of ERderived, Golgi-associated DOPr in cultured secretory PC12 cells in vitro (Kim and von Zastrow, 2003). This relatively acute NGF effect is in contrast to the long-term $(4 \mathrm{~h})$ NGF effect of DOPr translocation to surface membrane described in this study, and might serve as a parallel NGF effect that primes and replenishes the intracellular DOPr pool for surface trafficking. While we did not observe a significant increase in total DOPr protein after morphine treatment (Ma et al., 2006), upregulated NGF may increase the expression of many other downstream signaling proteins given its broad stimulating effect in neural protein expression, contributing to the NGF effect (Huang and Reichardt, 2003). For example, NGF treatment of PC12 cells increased expression of DOPr gene through epigenetic modifications (Chen et al., 2008). Previously reported, agonist- or depolarization-induced membrane trafficking of DOPr and TRP channels share a characteristic of rapid occurrence (within seconds to minutes) (Guan et al., 2005; Odell et al., 2005; Zhang et al., 2005), but clearly differ from the present finding of NGF-induced, slowly occurring (at least hours) translocation of synaptic DOPr. The latter may be indicative of extra layers of adaptive regulations at transcriptional and translational levels, and in the forward transportation of DOPr through the ER-Golgi-surface membrane secretory pathway.

Receptor exocytosis and insertion into surface membrane involve membrane fusion between plasma membrane and the membrane of receptor-containing vesicles (Pfeffer, 2007; Wojcik and Brose, 2007). The SNARE complex is a core execution component in the membrane fusion machinery. While much of our current understanding of SNARE-mediated fusion mechanisms has been derived from studies on fast (millisecond) synaptic release of neurotransmitters (Wojcik and Brose, 2007), emerging evidence suggests that re-
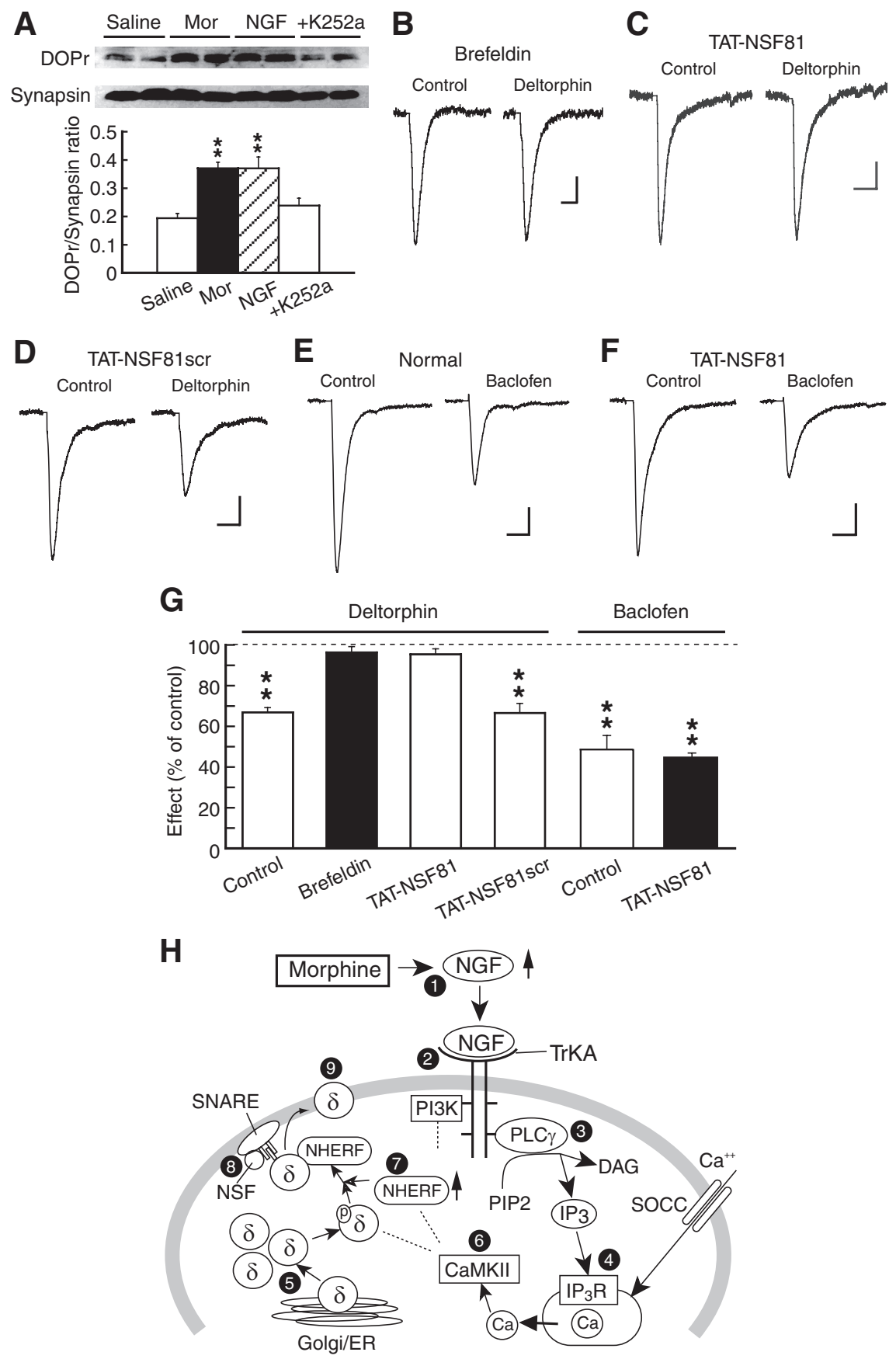

Figure 8. Morphine induction of DOPr involves DOPr translocation to surface membrane of synaptic terminals. $\boldsymbol{A}$, Western blot lanes of DOPr protein and the synaptic terminal marker synaptophysin (synapsin), and their ratio changes in NRM synaptosomes from rats treated with saline, morphine, NGF, or morphine plus K252a in vivo. B, Representative EPSCs in a slice from a morphinetreated rat and treated in vitro with long-period brefeldin A. C, D, Deltorphin actions on EPSCs in slices from morphine-treated rats and treated in vitro with the exocytosis-inhibiting peptide TAT-NSF $81(C)$ or with the corresponding but scrambled peptide TAT-NSF81scr (D) for $3 \mathrm{~h}$. $\boldsymbol{E}, \boldsymbol{F}$, Effects of the GABA receptor agonist baclofen $(10 \mu \mathrm{M})$ on EPSCs in NRM slices from morphinetreated rats without (normal) or with the TAT-NSF81 treatment in vitro. G, Group data showing the effects of deltorphin and baclofen in NRM slices of morphine-treated rats in control or after long-period treatment with the agents indicated. ${ }^{* *} p<0.01$. Calibration: $50 \mathrm{pA}$ and $10 \mathrm{~ms}$. H, Diagram of the proposed signaling pathways for DOPr trafficking on a central synaptic terminal. Chronic morphine upregulates NGF (1), which activates the TrKA receptor (2) and its coupled PLC $\gamma$ pathway (3) and PI3K pathway (downstream components to be investigated). $\mathrm{PLC} \gamma$ activation leads to production of IP3 and increased intracellular $\mathrm{Ca}^{2+}$ through $\mathrm{Ca}^{2+}$ release from the IP3 receptor (IP3R)-controlled $\mathrm{Ca}^{2+}$ store (4) and by $\mathrm{Ca}^{2+}$ influx through SOCC. DOPr is normally packed and transported through the ER/Golgi network and constitutively targeted to an intracellular pool (5). Increased intracellular $\mathrm{Ca}^{2+}$ activates CaMKII (6), which would lead to downstream changes in the expression of DOPr and NHERF-1 genes and proteins through yet unknown mechanisms of transcription and translation (7), resulting in an increased interaction between upregulated NHERF-1 and phosphorylated DOPr, and exocytotic translocation of intracellular DOPr to surface membrane. Interaction of DOPr-containing vesicles with the SNARE complex, whose function is regulated by NSF (8), causes membrane fusion for exocytosis and surface expression of functional DOPr (9). 
ceptor trafficking and surface delivery also involve SNAREdependent exocytosis (Lan et al., 2001). NSF, an ATPase associated with the SNARE complex, regulates exocytosis by disassembling the SNARE complex in the SNARE assemble/disassemble cycle necessary for normal SNARE functions (Zhao et al., 2007). We have developed the cell-penetrating peptide TAT-NSF81 that interrupts exocytosis by inhibiting NSF activity (Matsushita et al., 2005). Our observation of TAT-NSF81 blocking the surface recruitment of functional DOPr indicates that the DOPr recruitment likely requires $\mathrm{Ca}^{2+}$-dependent, NSF/SNARE-mediated exocytosis. We noticed a reduction in EPSC amplitude after the TAT-NSF81 pretreatment, which possibly reflects its inhibitory effect on SNAREdependent membrane fusion of synaptic vesicles for glutamate release. A short period of wash of the peptide appeared to partially recover its inhibition of glutamate release, but not the already translocated DOPr. In addition to regulating SNARE disassembly, NSF directly interacts with specific recycling sequences on the cytoplasmic terminal of receptors to regulate their membrane trafficking, including $\beta_{2}$-adrenergic receptors and AMPA glutamate receptors (Zhao et al., 2007; Hanyaloglu and von Zastrow, 2008). Therefore, it is also possible that TAT-NSF81 blocks DOPr translocation by disrupting direct NSF-DOPr interaction.

Functional interaction between DOPr and MOPr has been well documented in previous studies using behavioral and genetic approaches (Kieffer and Gavériaux-Ruff, 2002). It likely involves diverse mechanisms at multiple levels, including synergistic interaction at the receptor level as DOPr-MOPr heterodimers in enhancing morphine analgesia (Gomes et al., 2004). Our current finding provides another potential mechanism by which NGF functions as a link between sustained MOPr stimulation and increased function of synaptic DOPr at the cellular level.

Proper GPCR localization and signaling are required for normal cell functions, and GPCR mislocalization and resultant abnormal signaling cause diseases (Tan et al., 2004). For example, NGF-mediated rapid membrane insertion of TRPV1 channels by PI3 kinase-dependent phosphorylation likely accounts for hypersensitivity of peripheral sensory neurons under inflammatory pain sensitization (Ji et al., 2002; Zhang et al., 2005). Given the widespread DOPr distribution and its membrane trafficking found in pain-related central neurons and recently in drug addiction-related brain areas (Ma et al., 2006; Zhang et al., 2006; Cahill et al., 2007; Bie et al., 2009), NGF-regulated membrane trafficking of DOPr may represent another leap in the everdiversifying functions of this neurotrophin for GPCR signaling in the adult brain. In view of wide NGF involvement in many pathological conditions, such as tissue inflammation, nerve injury, drug addiction, behavioral stress, degenerative changes, and immune response-related diseases (Sofroniew et al., 2001), NGF control of GPCR trafficking may have broader functional implications as a potential cellular mechanism for synaptic alterations, abnormal cellular signaling, and system changes under those conditions (Poo, 2001; Collingridge et al., 2004; Hefti et al., 2006).

\section{References}

Bie B, Peng Y, Zhang Y, Pan ZZ (2005) cAMP-mediated mechanisms for pain sensitization during opioid withdrawal. J Neurosci 25:3824-3832.

Bie B, Zhu W, Pan ZZ (2009) Rewarding morphine-induced synaptic function of delta-opioid receptors on central glutamate synapses. J Pharmacol Exp Ther 329:290-296.

Cahill CM, Holdridge SV, Morinville A (2007) Trafficking of delta-opioid receptors and other G-protein-coupled receptors: implications for pain and analgesia. Trends Pharmacol Sci 28:23-31.
Chao MV, Bothwell M (2002) Neurotrophins: to cleave or not to cleave. Neuron 33:9-12.

Chen YL, Law PY, Loh HH (2008) NGF/PI3K signaling-mediated epigenetic regulation of delta opioid receptor gene expression. Biochem Biophys Res Commun 368:755-760.

Collingridge GL, Isaac JT, Wang YT (2004) Receptor trafficking and synaptic plasticity. Nat Rev Neurosci 5:952-962.

Dobrunz LE, Stevens CF (1997) Heterogeneity of release probability, facilitation, and depletion at central synapses. Neuron 18:995-1008.

Donaldson JG, Finazzi D, Klausner RD (1992) Brefeldin A inhibits Golgi membrane-catalysed exchange of guanine nucleotide onto ARF protein. Nature 360:350-352.

Dunkley PR, Jarvie PE, Robinson PJ (2008) A rapid Percoll gradient procedure for preparation of synaptosomes. Nat Protoc 3:1718-1728.

Finn AK, Whistler JL (2001) Endocytosis of the mu opioid receptor reduces tolerance and a cellular hallmark of opiate withdrawal. Neuron 32:829-839.

Ghijsen WE, Leenders AG, Lopes da Silva FH (2003) Regulation of vesicle traffic and neurotransmitter release in isolated nerve terminals. Neurochem Res 28:1443-1452.

Gomes I, Gupta A, Filipovska J, Szeto HH, Pintar JE, Devi LA (2004) A role for heterodimerization of mu and delta opiate receptors in enhancing morphine analgesia. Proc Natl Acad Sci U S A 101:5135-5139.

Guan JS, Xu ZZ, Gao H, He SQ, Ma GQ, Sun T, Wang LH, Zhang ZN, Lena I, Kitchen I, Elde R, Zimmer A, He C, Pei G, Bao L, Zhang X (2005) Interaction with vesicle luminal protachykinin regulates surface expression of delta-opioid receptors and opioid analgesia. Cell 122:619-631.

Hack SP, Bagley EE, Chieng BC, Christie MJ (2005) Induction of $\delta$-opioid receptor function in the midbrain after chronic morphine treatment. J Neurosci 25:3192-3198.

Hanyaloglu AC, von Zastrow M (2008) Regulation of GPCRs by endocytic membrane trafficking and its potential implications. Annu Rev Pharmacol Toxicol 48:537-568.

Hayashi Y, Shi SH, Esteban JA, Piccini A, Poncer JC, Malinow R (2000) Driving AMPA receptors into synapses by LTP and CaMKII: requirement for GluR1 and PDZ domain interaction. Science 287:2262-2267.

Hefti FF, Rosenthal A, Walicke PA, Wyatt S, Vergara G, Shelton DL, Davies AM (2006) Novel class of pain drugs based on antagonism of NGF. Trends Pharmacol Sci 27:85-91.

Heydorn A, Søndergaard BP, Ersbøll B, Holst B, Nielsen FC, Haft CR, Whistler J, Schwartz TW (2004) A library of 7TM receptor C-terminal tails. Interactions with the proposed post-endocytic sorting proteins ERM-binding phosphoprotein 50 (EBP50), N-ethylmaleimide-sensitive factor (NSF), sorting nexin 1 (SNX1), and G protein-coupled receptor-associated sorting protein (GASP). J Biol Chem 279:54291-54303.

Huang EJ, Reichardt LF (2003) Trk receptors: roles in neuronal signal transduction. Annu Rev Biochem 72:609-642.

Huang P, Steplock D, Weinman EJ, Hall RA, Ding Z, Li J, Wang Y, Liu-Chen LY (2004) kappa Opioid receptor interacts with $\mathrm{Na}(+) / \mathrm{H}(+)$-exchanger regulatory factor-1/Ezrin-radixin-moesin-binding phosphoprotein-50 (NHERF1/EBP50) to stimulate $\mathrm{Na}(+) / \mathrm{H}(+)$ exchange independent of $\mathrm{G}(\mathrm{i}) / \mathrm{G}(\mathrm{o})$ proteins. J Biol Chem 279:25002-25009.

Ji RR, Samad TA, Jin SX, Schmoll R, Woolf CJ (2002) p38 MAPK activation by NGF in primary sensory neurons after inflammation increases TRPV1 levels and maintains heat hyperalgesia. Neuron 36:57-68.

Kieffer BL, Gavériaux-Ruff C (2002) Exploring the opioid system by gene knockout. Prog Neurobiol 66:285-306.

Kim KA, von Zastrow M (2003) Neurotrophin-regulated sorting of opioid receptors in the biosynthetic pathway of neurosecretory cells. J Neurosci 23:2075-2085.

Lan JY, Skeberdis VA, Jover T, Grooms SY, Lin Y, Araneda RC, Zheng X, Bennett MV, Zukin RS (2001) Protein kinase C modulates NMDA receptor trafficking and gating. Nat Neurosci 4:382-390.

Lin RC, Scheller RH (2000) Mechanisms of synaptic vesicle exocytosis. Annu Rev Cell Dev Biol 16:19-49.

Liu-Chen LY (2004) Agonist-induced regulation and trafficking of kappa opioid receptors. Life Sci 75:511-536.

Ma J, Pan ZZ (2006) Contribution of brainstem GABA(A) synaptic transmission to morphine analgesic tolerance. Pain 122:163-173.

Ma J, Zhang Y, Kalyuzhny AE, Pan ZZ (2006) Emergence of functional \{delta\}-opioid receptors induced by chronic morphine. Mol Pharmacol 69:1137-1145. 
Matsushita K, Morrell CN, Lowenstein CJ (2005) A novel class of fusion polypeptides inhibits exocytosis. Mol Pharmacol 67:1137-1144.

Morinville A, Cahill CM, Aibak H, Rymar VV, Pradhan A, Hoffert C, Mennicken F, Stroh T, Sadikot AF, O’Donnell D, Clarke PB, Collier B, Henry JL, Vincent JP, Beaudet A (2004) Morphine-induced changes in $\delta$ opioid receptor trafficking are linked to somatosensory processing in the rat spinal cord. J Neurosci 24:5549-5559.

Odell AF, Scott JL, Van Helden DF (2005) Epidermal growth factor induces tyrosine phosphorylation, membrane insertion, and activation of transient receptor potential channel 4. J Biol Chem 280:37974-37987.

Pan ZZ, Tershner SA, Fields HL (1997) Cellular mechanism for antianalgesic action of agonists of the kappa-opioid receptor. Nature 389:382-385.

Patwardhan AM, Berg KA, Akopain AN, Jeske NA, Gamper N, Clarke WP, Hargreaves KM (2005) Bradykinin-induced functional competence and trafficking of the $\delta$-opioid receptor in trigeminal nociceptors. J Neurosci 25:8825-8832.

Paxinos G, Watson C (1986) The rat brain in stereotaxic coordinates, Ed 2. Sydney: Academic.

Pfeffer SR (2007) Unsolved mysteries in membrane traffic. Annu Rev Biochem 76:629-645.

Poo MM (2001) Neurotrophins as synaptic modulators. Nat Rev Neurosci 2:24-32.

Scherrer G, Imamachi N, Cao YQ, Contet C, Mennicken F, O'Donnell D, Kieffer BL, Basbaum AI (2009) Dissociation of the opioid receptor mechanisms that control mechanical and heat pain. Cell 137:1148-1159.

Shenolikar S, Voltz JW, Minkoff CM, Wade JB, Weinman EJ (2002) Targeted disruption of the mouse NHERF-1 gene promotes internalization of proximal tubule sodium-phosphate cotransporter type IIa and renal phosphate wasting. Proc Natl Acad Sci U S A 99:11470-11475.
Sofroniew MV, Howe CL, Mobley WC (2001) Nerve growth factor signaling, neuroprotection, and neural repair. Annu Rev Neurosci 24:1217-1281.

Tan CM, Brady AE, Nickols HH, Wang Q, Limbird LE (2004) Membrane trafficking of $\mathrm{G}$ protein-coupled receptors. Annu Rev Pharmacol Toxicol 44:559-609.

Tsao PI, von Zastrow M (2000) Type-specific sorting of G protein-coupled receptors after endocytosis. J Biol Chem 275:11130-11140.

Wang H, Pickel VM (2001) Preferential cytoplasmic localization of $\delta$-opioid receptors in rat striatal patches: comparison with plasmalemmal mu-opioid receptors. J Neurosci 21:3242-3250.

Weinman EJ, Hall RA, Friedman PA, Liu-Chen LY, Shenolikar S (2006) The association of NHERF adaptor proteins with g protein-coupled receptors and receptor tyrosine kinases. Annu Rev Physiol 68:491-505.

Whistler JL, Enquist J, Marley A, Fong J, Gladher F, Tsuruda P, Murray SR, Von Zastrow M (2002) Modulation of postendocytic sorting of G protein-coupled receptors. Science 297:615-620.

Williams JT, Christie MJ, Manzoni O (2001) Cellular and synaptic adaptations mediating opioid dependence. Physiol Rev 81:299-343.

Wojcik SM, Brose N (2007) Regulation of membrane fusion in synaptic excitation-secretion coupling: speed and accuracy matter. Neuron 55:11-24.

Zhang X, Huang J, McNaughton PA (2005) NGF rapidly increases membrane expression of TRPV1 heat-gated ion channels. EMBO J 24:42114223.

Zhang X, Bao L, Guan JS (2006) Role of delivery and trafficking of deltaopioid peptide receptors in opioid analgesia and tolerance. Trends Pharmacol Sci 27:324-329.

Zhao C, Slevin JT, Whiteheart SW (2007) Cellular functions of NSF: not just SNAPs and SNAREs. FEBS Lett 581:2140-2149. 